\title{
Archaeology and ethnography demonstrate a human origin for Amazonian Dark Earths
}

Morgan J. Schmidt 1,*, Manuel Arroyo-Kalin ${ }^{2}$, Helena P. Lima ${ }^{3}$, Claide de Paula Moraes ${ }^{4}$, Eduardo G. Neves ${ }^{5}$, Wenceslau Teixeira ${ }^{6}$, Michael Heckenberger ${ }^{7}$, Marco Madella ${ }^{8}$, S. Yoshi Maezumi ${ }^{9}$, Philip Riris ${ }^{10}$, Myrtle P. Shock ${ }^{4}$, Jennifer Watling ${ }^{5}$, Caroline Fernandes Caromano ${ }^{11}$, Bruno Moraes ${ }^{12}$, Gabriela Prestes-Carneiro ${ }^{4}$, Filippo Stampanoni Bassi $^{13}$, Marta Sara Cavallini ${ }^{5}$, Raoni Valle ${ }^{4}$, Carlos Francisco Brazão Vieira Alho ${ }^{14}$, Fernando Almeida ${ }^{15}$, Carlos Augusto Palheta Barbosa ${ }^{16}$, George Brown ${ }^{17}$, Leandro Matthews Cascon ${ }^{18}$, Charles R Clement ${ }^{19}$, Luis Cunha ${ }^{20}$, William M Denevan ${ }^{21}$, Carlos Fausto ${ }^{22}$, João Aires da Fonseca ${ }^{23}$, Bruna Franchetto ${ }^{22}$, Susanna Hecht ${ }^{24}$, Vinicius Honorato $^{4}$, André Braga Junqueira ${ }^{25}$, Thiago Kater ${ }^{5}$, Thomas W Kuyper ${ }^{26}$, Márjorie Lima ${ }^{5}$, Umberto Lombardo ${ }^{27}$, Rodrigo Santana Macedo ${ }^{28}$, Juliana Salles Machado ${ }^{29}$, Marcos Magalhães ${ }^{3}$, Francis E Mayle ${ }^{30}$, Doyle McKey ${ }^{31}$, Francisco Pugliese ${ }^{5}$, Fabiano Pupim ${ }^{32}$, Anne Rapp Py-Daniel ${ }^{4}$, Marco F Raczka ${ }^{30}$, Bruna Rocha ${ }^{4}$, Stéphen Rostain ${ }^{33}$, Eduardo Kazuo Tamanaha ${ }^{34}$, Thiago Trindade ${ }^{5}$

*email: morgansc@mit.edu

${ }^{1}$ Department of Earth Atmospheric and Planetary Sciences, Massachusetts Institute of Technology, Cambridge, USA

${ }^{2}$ Institute of Archaeology, University College London, United Kingdom

${ }^{3}$ Museu Paraense Emílio Goeldi, Belém, Brazil

${ }^{4}$ Instituto de Ciências da Sociedade, Universidade Federal do Oeste do Pará, Santarem, Brazil

${ }^{5}$ Museu de Arqueologia e Etnologia, Universidade de São Paulo, Brazil

${ }^{6}$ Embrapa Soils, Rio de Janeiro, Brazil

${ }^{7}$ Department of Anthropology, University of Florida, Gainesville, USA

${ }^{8}$ ICREA, CaSEs Research Group, Department of Humanities, Universitat Pompeu Fabra, Barcelona, Spain

${ }^{9}$ Institute for Biodiversity \& Ecosystem Dynamics, University of Amsterdam, The Netherlands

${ }^{10}$ Institute for Modelling Socio-Environmental Transitions, Bournemouth University, Germany

${ }^{11}$ Naturalis Biodiversity Center, Leiden, The Netherlands

${ }^{12}$ Amazon Hopes Collective

${ }^{13}$ Museu da Amazonia, Manaus, Brazil

${ }^{14}$ Wageningen University \& Research, The Netherlands

${ }^{15}$ Universidade Federal de Sergipe, Aracaju, Brazil

${ }^{16}$ Universidade Federal do Para, Belém, Brazil

${ }^{17}$ Embrapa Forestry, Colombo, Brazil

${ }^{18}$ Faculty of Archaeology, Leiden University, The Netherlands

${ }^{19}$ Instituto Nacional de Pesquisas da Amazonia, Manaus, Brazil

${ }^{20}$ Centre for Functional Ecology, Department of Life Sciences, University of Coimbra, Portugal

${ }^{21}$ Department of Geography, University of Wisconsin-Madison, USA

${ }^{22}$ Museu Nacional/ Universidade Federal do Rio de Janeiro, Brazil

${ }^{23}$ ArqueoMaquina, Belém, Brazil

${ }^{24}$ Institute of the Environment, University of California, Los Angeles, USA

${ }^{25}$ Institut de Ciència i Tecnologia Ambientals, Universitat Autònoma de Barcelona, Spain

${ }^{26}$ Soil Biology Group, Wageningen University, The Netherlands

${ }^{27}$ Institute of Geography, University of Bern, Switzerland

${ }^{28}$ Instituto Nacional do Semiárido (INSA), Campina Grande, Brazil

${ }^{29}$ Departamento de História, Universidade Federal de Santa Catarina, Florianópolis, Brazil

${ }^{30}$ School of Archaeology, Geography \& Environmental Science (SAGES), University of Reading, United Kingdom

${ }^{31}$ Centre d'Écologie Fonctionnelle et Évolutive (CEFE), University of Montpellier, France

${ }^{32}$ Department of Environmental Science, Federal University of São Paulo, Brazil

${ }^{33}$ French National Centre for Scientific Research, Paris, France

${ }^{34}$ Instituto de Desenvolvimento Sustentável Mamirauá, Tefé, Brazil

This preprint has been submitted for publication to Nature Communications as a Matters Arising in response to Silva, L. C. R. et al. (2021). "A new hypothesis for the origin of Amazonian Dark Earths." Nature Communications 12(1): 127. It has not been peer-reviewed. Subsequent versions of this manuscript may have slightly different content. Please feel free to contact the authors with any feedback. 
Archaeological research provides clear evidence that the widespread formation of Amazonian Dark Earths (ADEs) in tropical lowland South America was concentrated in the Late Holocene, an outcome of sharp demographic growth that peaked towards $1000 \mathrm{BP}(1-3)$. In their recent paper, however, Silva et al. (4) propose that the high fertility of ADE is not of anthropic origin but instead the result of alluvial deposition starting in the Middle Holocene (8200-4200 cal BP). In order to support this argument, they marshal data and observations from a single expanse of ADE, the archaeological site of Caldeirão, and disregard or misread other studies of ADEs in the Central Amazon region (5-7). Silva et al.'s claim, an epilogue to 'geogenic' models laid to rest over 40 years ago (8), also dismisses research showing how long-term anthropic soil enrichment occurs as a result of daily practices at contemporary indigenous settlements (Fig. 1a) (9-11). Here we critically review Silva et al.'s analysis and affirm that, like most ADEs, Caldeirão has anthropic soil horizons formed by burning, deposition, and reworking of refuse associated with indigenous settlement activities between 2500 and $500 \mathrm{BP}$.

In their paper, Silva et al. do not consider crucial information arising from the wellestablished archaeological chronology of the Central Amazon region, nor acknowledge the anthropogenic topography or stratigraphy of the Caldeirão ADE site (9). Research conducted at numerous archaeological sites in the Central Amazon (1) has shown that the largest ADE expanses record multi-component occupations that date to 1200-800 BP and are often underlain by remains of older (<2500 BP) ceramic occupations (Fig. 1b, 1c). Coring and excavation at multiple ADE sites, including Caldeirão, show that these are pottery-rich archaeological deposits modified by soil forming processes. Profiles routinely studied in excavations make it clear that upland ADEs in this region are formed on Tertiary-age surfaces rather than alluvial sediments. Studies of artefact spatial distribution, topography, and stratigraphy reveal that ADEs are predominantly humanmade assemblages of mounds, pits, ditches, paths, and other landscape interventions typical of settlements (Figure 2a-d). The transects used by Silva et al. to compare ADEs and Ultisols are entirely insensitive to this spatial and depth-wise variability in elemental enrichment (Figure 2e). A lack of appreciation for stratigraphy is also evident in Silva et al.'s suggestion that middle Holocene charcoal provides an accurate age marker for the beginning of ADE formation. Regardless of whether it is the result of anthropic or natural fires, the dated charcoal fragments from $>80 \mathrm{~cm}$ have no stratigraphic association with ADE deposits. Radiocarbon dates of charcoal associated with the regionally well-established typology of ceramic artefacts from ADE deposits are a far more precise means to date ADE formation. At Caldeirão, they clearly point to Late Holocene occupations (12).

Silva et al. argue that a late Holocene onset for incipient agriculture in the Central Amazon region would preclude populations large enough to produce the levels of elemental enrichment recorded at Caldeirão. This argument is supported by overgeneralized ideas about plant cultivation, sedentism, population growth, and ADEs in ancient Amazonia. Their view rejects anthropic factors as main drivers for soil enrichment, both excluding inputs from domestic waste and arguing that indigenous land use regimes cannot produce comparable enrichment. However, ethnographic evidence shows that the highest elemental enrichment in ADEs reflects inputs associated with settlement refuse rather than agricultural management (9), which in ancient Amazonia was based on polyculture agroforestry of domesticated and nondomesticated plants in both extensive and intensive systems (13-14). Both high elemental enrichment and soil modification associated with settlement practices, as well as microfossils of maize, palms and tubers, revealing use of agroforestry systems, are found at the nearby site of Hatahara $(6,15)$, less than $4 \mathrm{~km}$ away and contemporaneous with the Caldeirão archaeological 
occupation. As regards sedentism and population growth, ADEs containing large quantities of ceramics and earthen features that developed over a clearly-dated chronological range are, by far, the best proxy for sedentary settlement and rising population density in the past $(2,3,5,16)$. Silva et al.'s references to the limitations of incipient agriculture or low population levels, which hinge on the acceptance of a middle Holocene age for ADE formation at Caldeirão and, more generally, on the premise that ADEs were initially established for agricultural purposes, are entirely misplaced.

Silva et al.'s claim that it is unknown how indigenous populations relying on incipient agriculture, aquatic wildlife, and hunting could have created areas of persistent high fertility, shows a lack of awareness of decades of research on the subject. Ethnoarchaeology has shown that soil enrichment and ADE formation are consistently associated with domestic activities in indigenous villages. Research with the Kuikuro community, who are fisher-cultivators that live in the Upper Xingu region, has demonstrated that the greatest enrichment in elements such as $\mathrm{P}$, $\mathrm{Ca}$, and $\mathrm{Sr}$, as well as high organic carbon and nearly neutral $\mathrm{pH}$, occurs in mounded refuse middens. Once the enriched soil horizons are formed they are often used for cultivating crops such as maize, sweet potato, and manioc, among others (9). Contrary to Silva et al.'s claim, this elemental enrichment accumulates in settlements and is then used for cultivation, not the other way around. This explanation does not require a flooding scenario to account for ADE fertility.

In the Central Amazon region, the pattern of ADEs associated with mounds on bluffs above the highest flooding line of the Solimões River is repeated at other archaeological sites near Caldeirão, such as Laguinho, Lago Grande, and Hatahara $(5,6)$. At a broader regional scale, Silva et al.'s fluvial hypothesis cannot account for the wide range of geomorphic settings in which ADEs are found, including higher altitude locations and along rivers with greatly varying quantities of suspended sediment. For instance, the 90-ha Açutuba archaeological site, located 25 km north of Caldeirão, shows significant enrichment in $\mathrm{Ca}, \mathrm{P}$, and other elements, like other ADEs (6). However, it sits on a non-flooding high bluff that overlooks the Negro River, which has an average suspended sediment load $<5 \%$ of the Solimões River (17). East of the Central Amazon region, the 20-ha Cipoal do Araticum archaeological site is an ADE up to $2 \mathrm{~m}$ in depth. Yet, it is located between plateaus adjacent to only small headwater streams and springs (18), precluding significant alluvial inputs. West of the Central Amazon region, some of the wellstudied ADEs of the middle Caquetá River are formed on soils mantling the Araracuara sandstone massif (19). Their locations some 90 meters above the maximum flood stage precludes flood-related alluvial inputs.

We could highlight many more examples. However, we are reminded of the insights offered many decades ago by archaeologist and ethnologist Curt Nimuendajú (20), who argued that the landscape position, size, soil texture, and ceramic contents of ADEs could only occur if these restricted soil expanses formed in old indigenous settlements. The results of archaeological and ethnographic research carried out since then confirm this interpretation and reject Silva et al.'s geogenic hypothesis. 


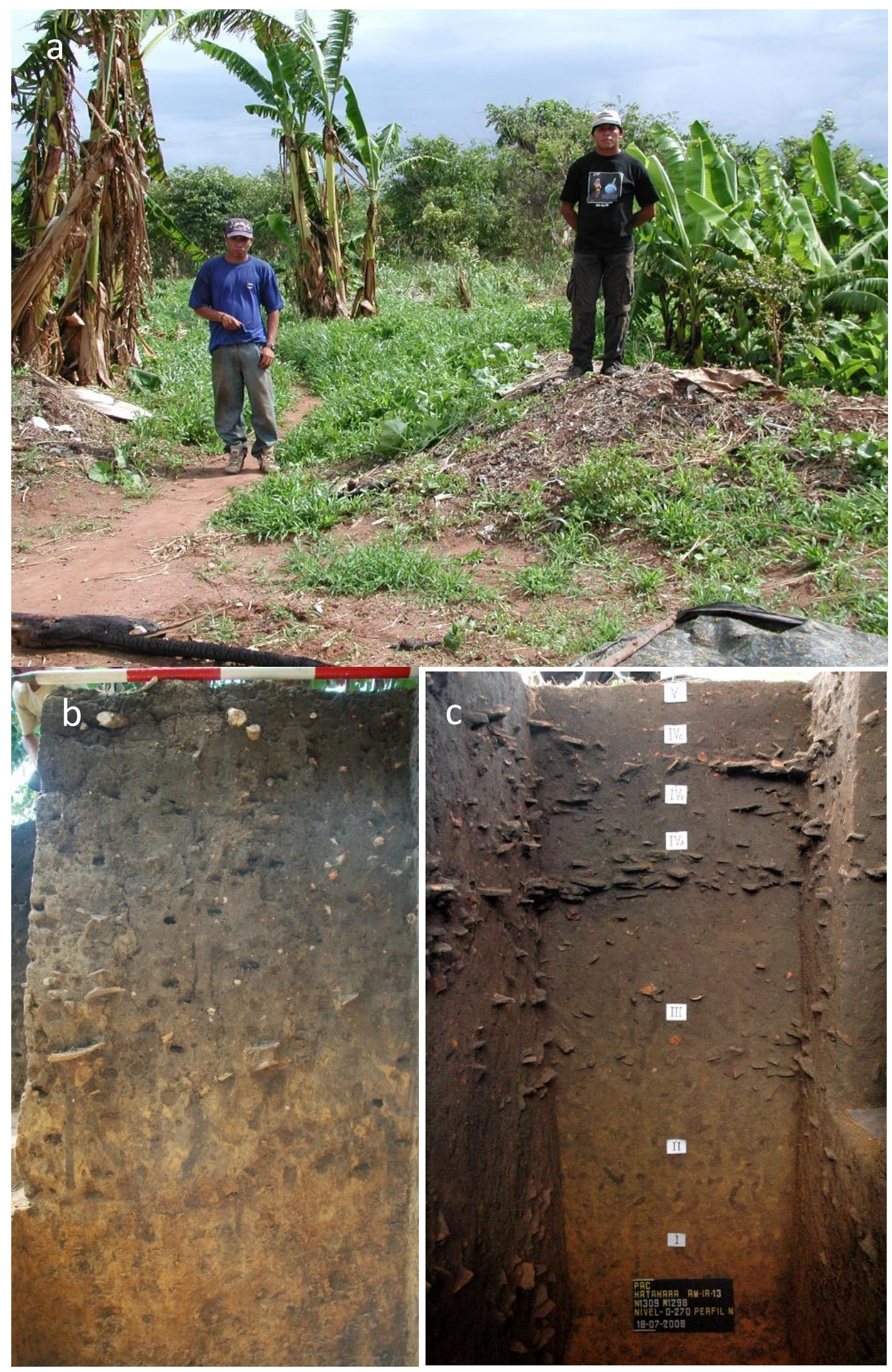

Fig. 1 a Mounded trash middens on the edge of a yard in an indigenous Kuikuro village ${ }^{5}$. b-c vertical profiles exposed by archaeological excavations at the Hatahara ADE site. b samples a flat area of the ADE. c samples a raised area of the ADE. Note pottery fragments stratified below the darkened ADE sediments. 


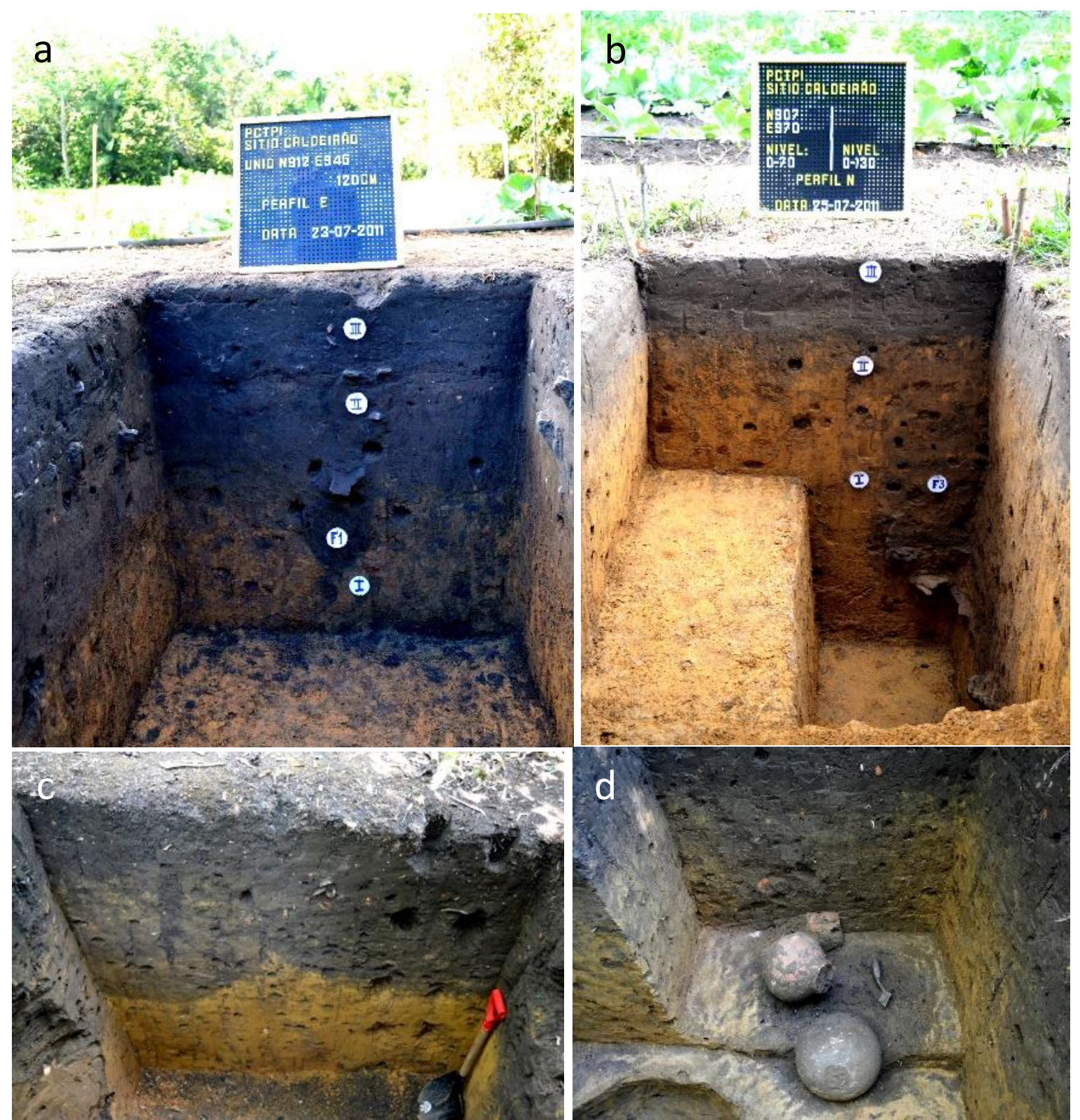

Fig. 2 a-d Archaeological excavation profiles at the Caldeirão ADE site. Vertical profiles exposed by multiple archaeological excavations. Note clearly defined archaeological matrix features infilled with ADE sediment (2c), and infilled pit feature with well-preserved ceramic vessels (2d) (See map in Fig. 2e below for locations). 


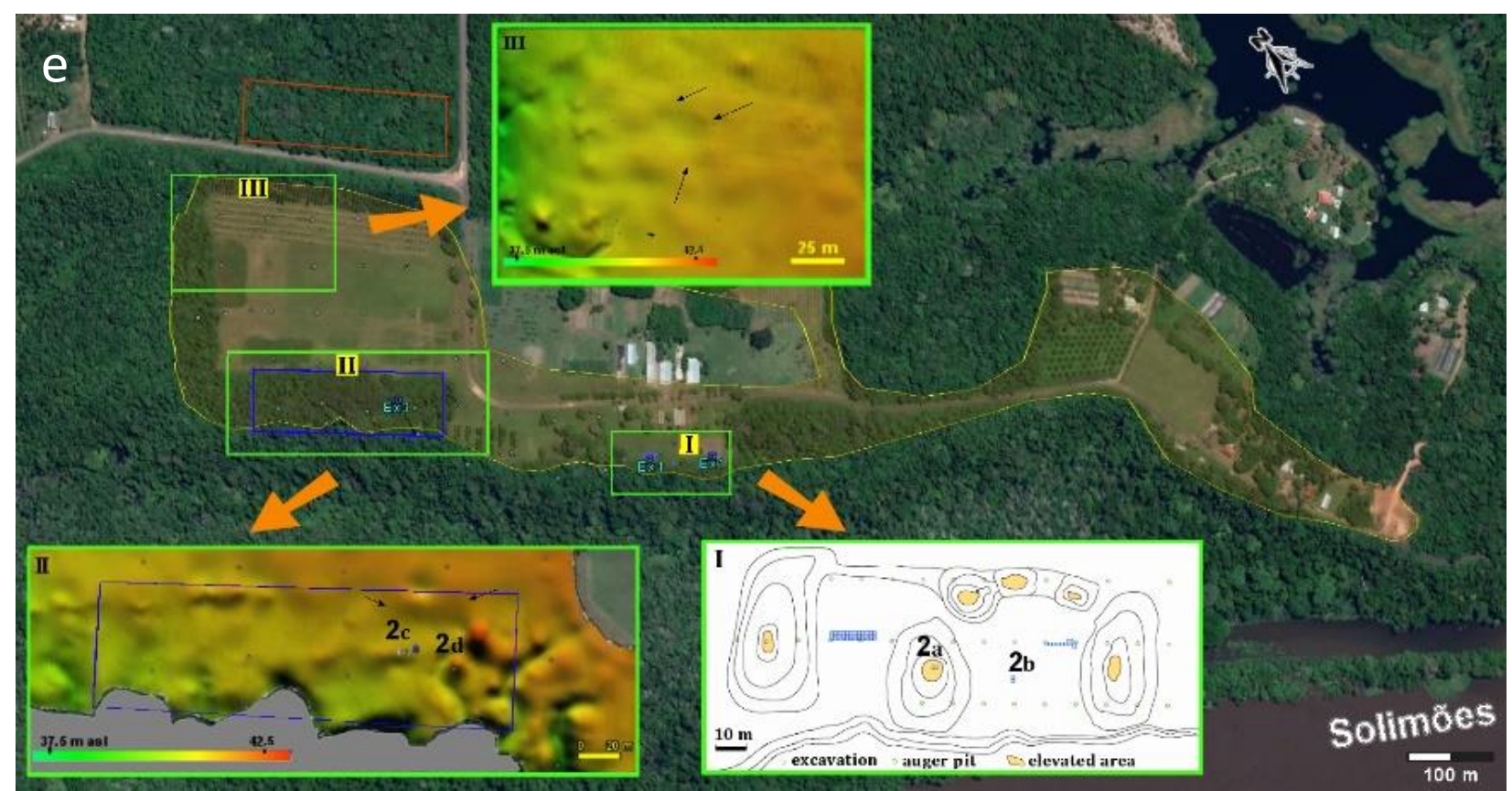

Fig. 2 e Map of the Caldeirão ADE site. Google Earth image of the site (see location of profiles $2 \mathrm{a}-\mathrm{d}$ within insets I and II). $2 \mathrm{a}$ and $\mathrm{b}$ are approximately 25 meters apart and show the stratigraphy of archaeological deposits in a mound (2a) and flat area (2b). $2 \mathrm{c}$ and $2 \mathrm{~d}$ are approximately 12 meters apart and show the stratigraphy of archaeological deposits at an Embrapa reference profile (c) and nearby archaeological excavation (d). The yellow shaded area shows the spatial distribution of mounds and archaeological pottery ascertained through archaeological survey and excavation. Insets I, II, III show details of the topography and/or archaeological excavations, as well as sampling locations for profiles depicted in Figures $2 \mathrm{a}-\mathrm{d}$. Inset II: Note the close proximity between identified mounded areas (black arrows), archaeological excavations, and the area of ADE sampled by Silva et al. (blue rectangle). Inset III: Survey has also identified mounded areas (black arrows) near the area Silva et al. sampled for Ultisols (red rectangle).

\section{References}

1. Neves, E. G. in Ancient Amazonia (Hornborg, A. \& Hill, J. D. eds.) (University Press of Colorado, 2011).

2. Arroyo-Kalin, M. \& Riris, P. Did pre-Columbian populations of the Amazonian biome reach carrying capacity during the Late Holocene? Phil. Trans. R. Soc. B 376: 20190715 (2021) (doi:10.1098/rstb.2019.0715).

3. Moraes, C. de P. \& Neves, E. G. O ano 1000: Adensamento populacional, interação e conflito na Amazônia Central. Amazônica 4, 122-148 (2012) (doi:10.18542/amazonica.v4i1.884)

4. Silva, L. C. R. A new hypothesis for the origin of Amazonian dark earths. Nature Communications 12, 127 (2021) (doi:10.1038/s41467-020-20184-2).

5. Schmidt, M. J. et al. Dark earths and the human built landscape in Amazonia: a widespread pattern of anthrosol formation. J. Archaeol. Sci. 42, 152-165 (2014) (doi:10.1016/j.jas.2013.11.002). 
6. Arroyo-Kalin, M., Neves, E. G. \& William I. Woods. in Amazonian Dark Earths: Wim Sombroek's Vision (Woods, W.I. et al. eds.) (Springer, 2009).

7. Macedo, R. S., Teixeira, W. G., Corrêa, M. M., Martins, G. C. \& Vidal-Torrado, P. Pedogenetic processes in anthrosols with pretic horizon (Amazonian Dark Earth) in Central Amazon, Brazil. PLOS ONE 12, e0178038 (2017) (doi:10.1371/journal.pone.0178038).

8. Smith, N. K. H. Anthrosols and human carrying capacity in Amazonia. Ann. Assoc. Am. Geogr. 70, 553-566 (1980) (doi: 10.1111/j.1467-8306.1980.tb01332.x).

9. Schmidt, M. J. Amazonian dark earths: Pathways to sustainable development in tropical rainforests? Bol. Mus. Para. Emílio Goeldi v. 8, n. 1, p. 11-38 (2013).

10. Hecht, S. B. in Amazonian Dark Earths: Origin, Properties, Management (eds. Lehmann, J., Kern, D. C., Glaser, B. \& Woods, W.) (Kluwer Academic Publishers, 2003).

11. Kern, D. C. et al. Terras pretas: Approaches to formation processes in a new paradigm. Geoarchaeology 32, 694-706 (2017) (doi: 10.1002/gea.21647).

12. Schellekens, J. et al. Molecular composition of several soil organic matter fractions from anthropogenic black soils (Terra Preta de Índio) in Amazonia - A pyrolysis-GC/MS study. Geoderma 288, 154-165 (2017) (doi:10.1016/j.geoderma.2016.11.001).

13. Neves, E. G. \& Heckenberger, M. J. The call of the wild: Rethinking food production in ancient Amazonia. Annu. Rev. Anthropol. 48, 371-388 (2019) (doi:10.1146/annurev-anthro-102218-011057).

14. Iriarte, J. et al. The origins of Amazonian landscapes: Plant cultivation, domestication and the spread of food production in tropical South America. Quat. Sci. Rev. 248, 106582 (2020)

(doi:10.1016/j.quascirev.2020.106582).

15. Caromano, C. F., Cascon, L. M., Neves, E. G. \& Scheel-Ybert, R. Revealing fires and rich diets: macro and micro-archaeobotanical analysis at the Hatahara site, Central Amazonia. Tipití J. Soc.

Anthropol. Lowl. S. Am. 11, 40-51 (2013).

16. Neves, E. G., Guapindaia, V. L. C., Lima, H. P., Costa, B. L. S., \& Gomes, J. in Amazonía. Memorias de las Conferencias Magistrales del 3er Encuentro Internacional de Arqueología Amazónica (ed. Stéphen Rostain) (Ministerio Coordinador de Conocimiento y Talento Humano/IKIAM, 2014).

17. Heckenberger, M. J., Petersen, J. B. \& Neves, E. G. Village size and permanence in Amazonia: two archaeological examples from Brazil. Lat. Am. Antiq. 10, 353-376 (1999) (doi: 10.2307/971962).

18. Guapindaia, V. \& da Fonseca, J. A. Metodologia de delimitação no sítio arqueológico Cipoal do Araticum na região do rio Trombetas, Pará, Brasil. Bol. Mus. Para. Emílio Goeldi Ciênc. Humanas 8 , 657-673 (2013) (doi:10.1590/S1981-81222013000300011).

19. Eden, M. J., Bray, W., Herrera, L. \& McEwan, C.. Terra preta soils and their archaeological context in the Caquetá basin of southeast Colombia. Am. Antiq. 49, 125-140 (1984) (doi: 10.2307/280517).

20. Stenborg, P. (ed.). In pursuit of a past Amazon. Archaeological researches in the Brazilian Guyana and in the Amazon region. By Curt Nimuendaú. vol. 45 (Värlskulturmuseet i Göteborg, 2004). 


\section{Author Contributions}

M.J.S., M.A.K., H.P.L., C.P.M., E.G.N., and W.T. co-wrote the manuscript and prepared the figures.

M.H., M.M., S.Y.M., P.R., M.P.S., and J.W. edited and commented on the manuscript. H.P.L., B.M.,

E.G.N., M.J.S., C.F.C., G.P.C., F.S.B., M.S.C. and R.V. carried out archaeological fieldwork at

Caldeirão site and commented on the manuscript. All other authors commented on the manuscript.

\section{Competing Interests}

The authors declare no competing interests. 